[Agr. Biol. Chem., Vol. 36, No. 4, p. 588 595, 1972]

\title{
Bitter Peptides in Cow Milk Casein Digests with Bacterial Proteinase
}

\author{
Part I. Isolation and Determination of Amino Acid Sequence \\ of a Bitter Peptide
}

\author{
By Noshi Minamiura, Yoshikazu Matsumura, Juichiro Fukumoto \\ and Takehiko Yamamoto
}

Faculty of Science, Osaka City University, Sumiyoshi-ku, Osaka

Received September 2, 1971

\begin{abstract}
Isolation and determination of amino acid sequence of the bitter peptides formed in the digestion of cow milk casein with alkaline proteinase of Bacillus subtilis were investigated. The casein digest with the enzyme was extracted with butanol and the extracted bitter peptides were fractionally purified by treating with several other organic solvents followed by subjecting to chromatography and gel-filtration. The amino acid sequence of one of the bitter peptides was determined as follows: Arg.Gly.Pro.Pro.Phe-Ileu.Val. Liberation of N-terminal Arg with trypsin or bacterial aminopeptidase did not affect the bitterness. Also, splitting off of Val and Ileu or Ileu. Val at the C-terminus by carboxypeptidase, or a bacterial neutral proteinase gave no influence on the bitterness. However, liberation of Arg and Gly from the peptide with bacterial aminopeptidase gave rise to a non bitter peptide.
\end{abstract}

Our previous paper ${ }^{1,2}$ have reported that digestion of proteins by proteolytic enzymes is always accompanied by formation of bitter substances. Character and thickness of the bitterness were varied according to the kind of protein to be digested and to the proteolytic enzyme employed for digestion. Among several proteins, cow milk casein and zein usually gave the most thick bitterness when digested with proteolytic enzymes. Also, the proteolytic enzymes of which optimal pHs were at neutral and alkaline sides generally gave more bitterness as compared with the enzymes of which optimal $\mathrm{pH}$ lied at acid sides.

The present paper deals with studies of isolation and determination of amino acid sequence of one of the bitter peptides isolated from the digests of cow milk casein with alkaline proteinase of Bacillus subtilis. ${ }^{31}$ The present paper also describes a method of determination of amino acid sequence of peptides using bacterial aminopeptidase, ${ }^{4}$ and some discussions about the experimental resultse obtained.

\section{MATERIALS AND METHODS}

1. Alkaline proteinase of Bacillus subtilis. In the present paper, a crystalline preparation of alkaline proteinase of starch liquefying $\alpha$-amylase-producing Bacillus subtilis was used which was obtained by the method reported previously by some of the present authors. ${ }^{3}$ Activity assay of the proteinase was carried out according to the method described in the above paper. The enzyme preparation showed 2200 units of activity per $\mathrm{mg}$ protein.

2. Aminopeptidase and other proteolytic enzymes. Aminopeptidase (SAPI) isolated by our method from the cells of saccharifying $\alpha$-amylase-producing Bacillus 
subtilis thas used of which activity was 38 units per mg protein. Trypsin and carboxypeptidase 1 were purchased from Seikagaku Kogyo Co., Ltd. The neutral proteinase of saccharifying $\alpha$-amylase-producing Bacillus subtilis was also purchased from Seikagaku Kogyo Co., Lid.

3. Cow milk casein. Cow milk casein was obtained from Wako Pure Chemical Industrial Ltd., and it was washed with $50 \circ$ o cold ethanol and dried in vacuo in order to remove some impurities before use. The casein was dissolved in a dilute sodium hydroxide solution ( $\mathrm{pH} 9.0$ ) at $60^{\circ} \mathrm{C}$ and for formation of bitter peptides it was digested with the bacterial proteinase ( $800 \mathrm{mg}$ proteinase per $\mathrm{kg}$ casein) at $40^{\circ} \mathrm{C}$ for $20 \mathrm{hr}$ to obtain about $15 \%$, hydrolysis degree by the ninhydrin method. ${ }^{5}$

4. Isolation and purification of bitter peptides. The cow milk casein digested with the alkaline proteinase was extracted with an equal volume of butanol at room temperature, and after the $\mathrm{pH}$ of the digests was adjusted to 4.5 with hydrochloric acid, the butanol phase was dried in vacuo. The residue was extracted with five volumes of hot ethanol and the ethanol solution was again dried in vacuo. The residue obtained in a powder form was suspended in ten rolumes of water and after heating at $80^{\circ} \mathrm{C}$ for $30 \mathrm{~min}$, the supernatant was separated by centrifugation. This supernatant was dried in vacuo and the residue was successively washed with cold acetone and ether to bring it to dryness. This dried residue was subjected to column chromatography for further purification of bitter peptides.

5. Determination of bitterness. The degree of bitterness was determined by the sensory test by several young men and women.

6. The investigation method of amino acid sequence of bitter peptides. The dinitrofluorobenzene method according to Sanger ${ }^{6}$ and the aminopeptidase method4i which had been developed by the present authors were applied for determination of amino acid sequence of bitter peptides.

\section{RESULTS}

\section{Isolation of bitter peptides}

The dried powder of crude bitter peptides obtained in Materials and Methods was sub- jected to gel filtration by a column of Sephadex G-25. The result is illustrated in Fig. 1, showing that the bitterness appeared separating into two fractions, BPI and BPII. The front fraction, BPI, was purified by a column of DEAE-Sephadex A-25 eluting with a linear gradient increase of ammonium acetate $(0$ to $0.6 \mathrm{M}$ ) by which procedure BPI was further separated into two fractions, BPIa and PBIb, as shown in Fig. 2. BPIa was treated by a column of SE-Sephadex C-25 to purify highly, as shown in Fig. 3. After passing through a column of Sephadex G-15 for desalting, BPIa was purified by a preparative paper chromatography and the bitter peptide BPIa was isolated as a chromatographically pure peptide. The purified bitter peptide was eluted with water from the paper, and after passing through a column of Sephadex G-15, it was concentrated in vacuo and dried over phosphorus pentaoxide in a desiccator. The yield of BPIa was nearly $2.0 \mathrm{~g}$ per $1.0 \mathrm{~kg}$ cow milk casein and the bitterness was felt even

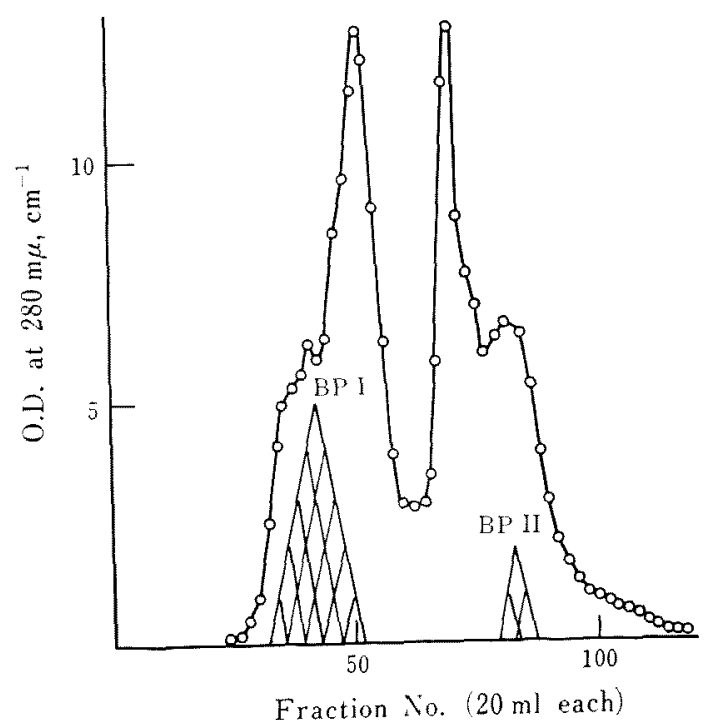

FIG. 1. Gel-Filtration of Crude Bitter Peptides on Sephadex G-25.

Column, $3.2 \times 125 \mathrm{~cm} ;$ crude bitter peptides applied, $20 \mathrm{ml}, E_{\mathrm{c} . \mathrm{mm}}^{280 \mathrm{~m}}=810$; flow rate, $50 \mathrm{ml} / \mathrm{hr}$. 


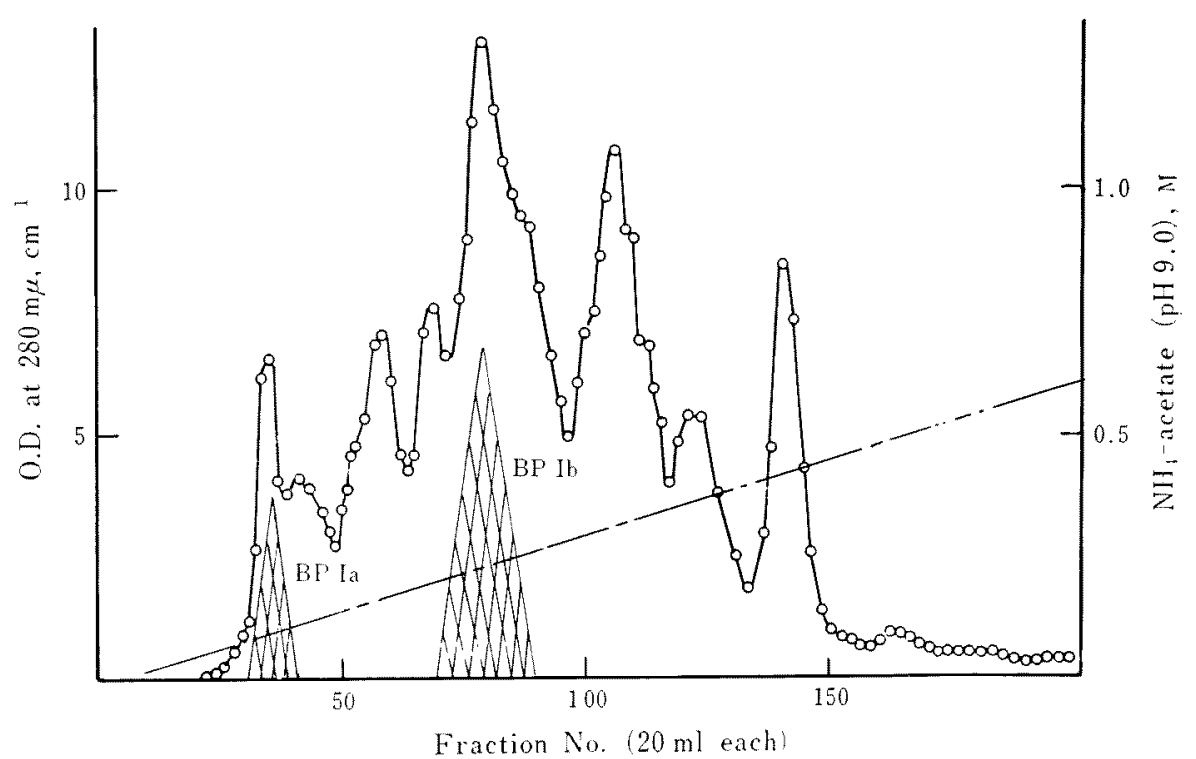

FIG. 2. Chromatography on DEAE-Sephadex A-25 of BPI Separated by Sephadex G-25 in Fig. 1.

Column, $3.2 \times 110 \mathrm{~cm}$; BPI applied, $80 \mathrm{ml}, E_{\mathrm{c} \cdot \mathrm{m}}^{220 \mathrm{~m} \prime \prime}=210$; flow rate. $30 \mathrm{ml}$ hr.

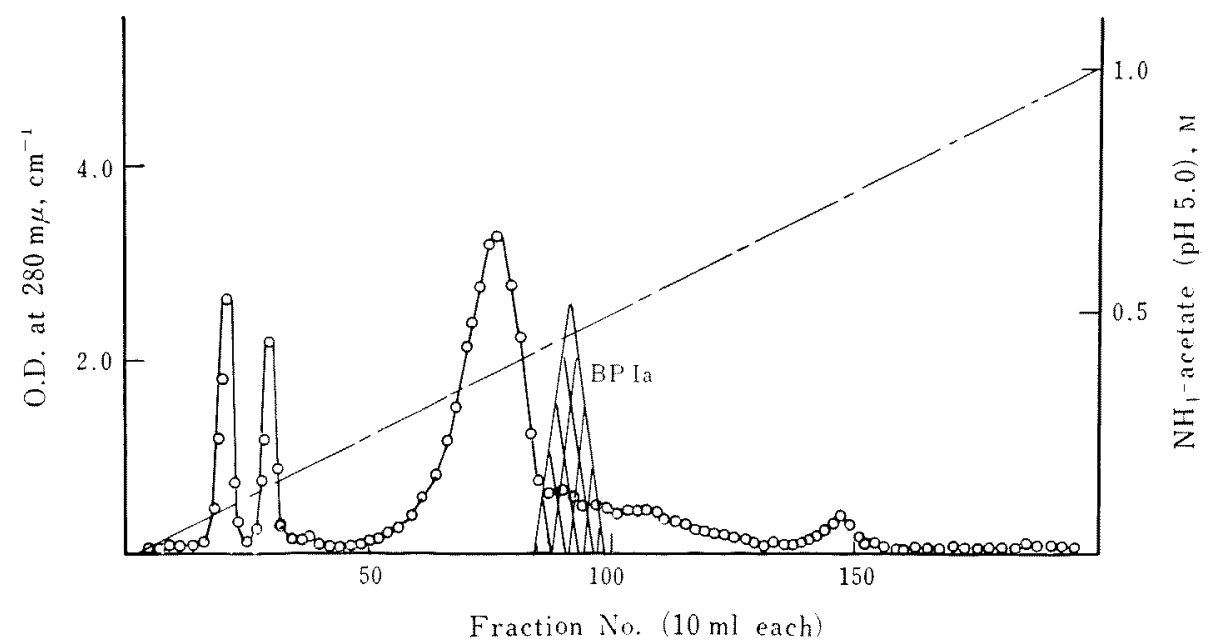

FIG. 3. Chromatography on SE-Sephadex $C_{-}-25$ of BPIa Separated by DEAE-Sephadex A-25 in Fig. 2.

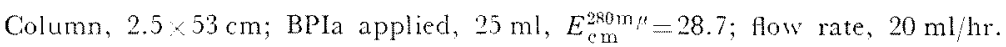

with a solution of $0.01 \mathrm{mg}$ of the peptide in and aminopeptidase.

$0.05 \mathrm{ml}$.

\section{Amino acids composition of BPIa}

The amino acids composition was investigated on hydrolysates of the peptide by acid
A $0.23 \mathrm{ml}$ aliquot of $1.0 \%$ solution of BPIa was mixed with an equal volume of $12 \mathrm{~N}$ hydrochloric acid and the mixture was hydrolyzed in an evacuated sealed tube at $110^{\circ} \mathrm{C}$ for $24 \mathrm{hr}$. The hydrolysate was then brought 
to dryness over sodium hydroxide flaskes in an evacuated desiccator. The dried hydrolysate was dissolved in $0.4 \mathrm{ml}$ of $0.067 \mathrm{M}$ citrate buffer, pH 2.2, and $0.5 \mathrm{ml}$ aliquot of the solution was subjected to amino acid autoanalyzer (Hitachi 043). The result is presented in Table I, showing that the peptide was consisting of six kinds of amino acid including two residues of proline and its molecular weight was estimated to be 785 .

On the other hand, $0.05 \mathrm{ml}$ of $2.0 \% \mathrm{BPIa}$ was added to a mixture of $0.05 \mathrm{ml}$ of aminopeptidase (total aminopeptidase activity, 1.2U), $0.05 \mathrm{ml}$ of $\mathrm{M} / 10$ tris(hydroxymethyl)aminomethane, $\mathrm{pH} 9.2$, and $0.05 \mathrm{ml}$ of $\mathrm{M} / 100$ cobalt-

Table I. Amino Acid Composition of BPIa

\begin{tabular}{lcc}
\hline Amino acid & Moles found & $\begin{array}{c}\text { No. of residues } \\
\text { per mole }\end{array}$ \\
\hline Proline & 0.723 & 2 \\
Glycine & 0.366 & 1 \\
Valine & 0.304 & 1 \\
Isoleucine & 0.270 & 1 \\
Phenylalanine & 0.358 & 1 \\
Arginine & 0.339 & 1 \\
\hline
\end{tabular}

ous acetate and the mixture was incubated at $30^{\circ} \mathrm{C}$ for $8 \mathrm{hr}$. The mixture was then analyzed by the descending paper chromatography using butanol-acetic acid-water $(4: 1: 2)$ and after the paper had been dried and sprayed with ninhydrin, the developed color density was measured at $563 \mathrm{~m} \mu$ using a self recording densitometer (Toyo Densitorol). Proline was detected by the reaction with isatin $^{71}$ and for quantitative determination the color density was read at $660 \mathrm{~m} \mu$. The amino acids composition of BPIa thus obtained and corrected comparing with known amounts of those amino acids on paper was found to be quite the same with that in Table I.

\section{Amino acid sequence of BPIa}

$\mathrm{BPIa}, 3.9 \mathrm{mg}$, was incubated with $100 \mu \mathrm{g}$ bacterial proteinase at $\mathrm{pH} 7.4$ and $30^{\circ} \mathrm{C}$ for $4 \mathrm{hr}$. The hydrolysate was then devided into two portions and to the one was added $50 \mu \mathrm{g}$ of trypsin, incubating the mixture for another $4 \mathrm{hr}$. The hydrolysates thus prepared were subjected to zone paper chromatography and the peptides and amino acids obtained there

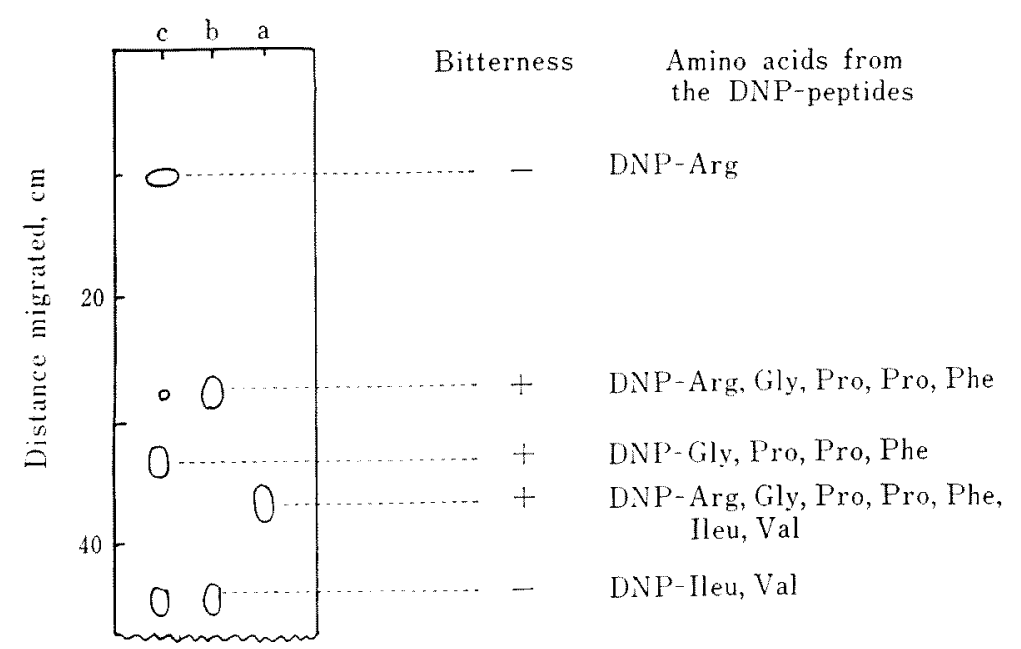

FIG. 4. Hydrolysis of BPIa with Bacterial Neutral Proteinase and Trypsin and Amino Acids Composition of Dinitrophenylated Derivatives of the Hydrolysates.

a, BPIa; b, hydrolysates with neutral proteinase; $\iota$, hydrolysates at first with neutral proteinase and then with trypsin. 
were extracted and dinitrophenylated, respectively. The dinitrophenylated compounds were hydrolyzed with $6 \mathrm{~N}$ hydrochloric acid and the constituting amino acids were investigated. The results are summarized in Fig. 4, showing that BPIa was hydrolyzed into two peptides with neutral proteinase of Bacillus subtilis and dinitrophenylated derivatives of the resulting peptides were consisting of DNPIleu-Val and DNP-Arg.(Gly, Pro, Pro, Phe), respectively. On the other hand, dinitrophenylation of a further hydrolysate with trypsin of the neutral proteinase digests of BPIa gave DNP-Arg and DNP-Gly (Pro, Pro, Phe), in addition to DNP-Ileu.Val. Amino acid sequence of BPIa will thus be concluded

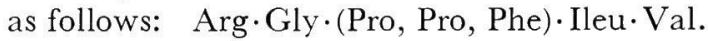

Determination of amino acid sequence of BPIa by applying bacterial aminopeptidase gave the same result. BPIa was incubated with aminopeptidase under the same condition as described in experiment on amino acid composition of BPIa, only that the $\mathrm{pH}$ of the reaction mixture was adjusted to $6.0,8.2$, or 9.2 with acetate- or tris buffer in the presence of $2.5 \times 10^{-3} \mathrm{M}$ of $\mathrm{Mn}^{2+}$ or $\mathrm{Co}^{2+}$ At certain intervals of time, $10 \mu \mathrm{l}$ aliquots of the reaction mixture were taken and spotted on a filter paper. In order to stop the enzyme reaction, the spotted area was immediately acidified with a trace amount of $2.0 \mathrm{M}$ acetic acid and dried in currenting air. The results of progressive paper chromatography with the reaction mixture are presented in Fig. 5, clearly showing that the degree of amino acid liberation was quite a function of incubation period of the reaction mixture. Color densities of the paper chromatograms in Fig. 5 were measured by a densitometer, the results representing the progressive curves of hydro-

FIG. 5. Progressive Paper Chromatography of the Hydrolysates of BPIa with Aminopeptidase.

Spots in the darkened area indicate proline which was detected by the isatin reaction method.

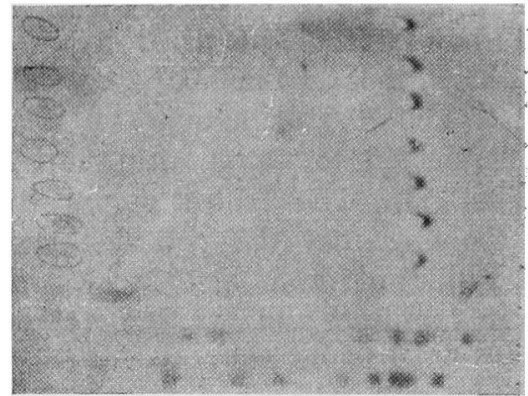

$8 \mathrm{hr}$

4 "

$2 " 1$

11

$30 \mathrm{~min}$

15 "I

7.5 II

BP Ia

Marker a.a. 2

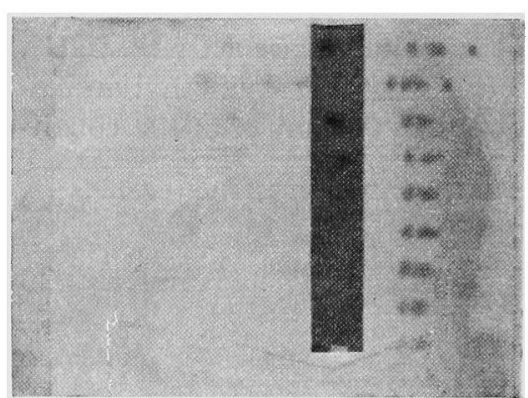

Marker a.a. 2

a.a. 1

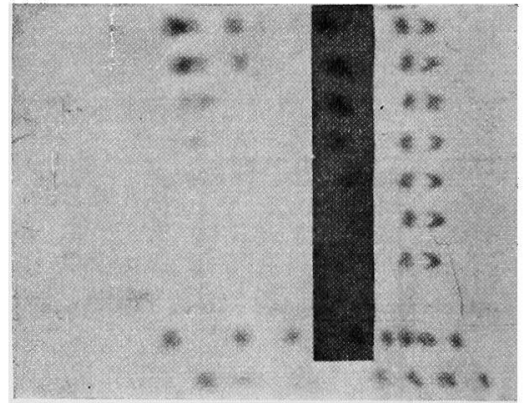

$8 \mathrm{hr}$

4 "

2 "

11

$30 \mathrm{~min}$

$15 "$

$7.5 "$

$8 \mathrm{hr}$

$2 \prime \prime$

$1 "$

$30 \mathrm{~min}$

15 "

$7.5 \prime \prime$

BP Ia

BP Ia

Marker a.a. 1

II a.a. 2

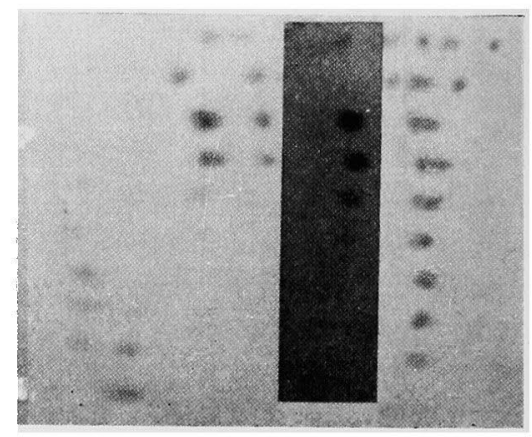

Marker a.a. 2

II a.a. 1

$8 \mathrm{hr}$

4 II

2 "I

1 II

$30 \mathrm{~min}$

$15 \prime$

$7.5 \prime$

BP Ia 


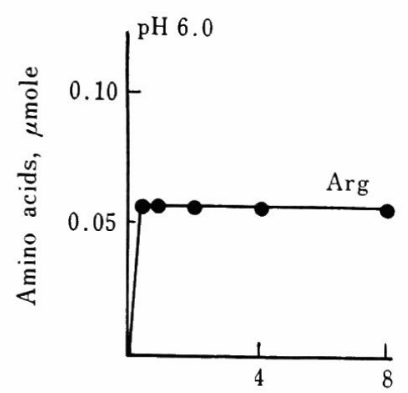

With $\mathrm{Co}^{2+}$
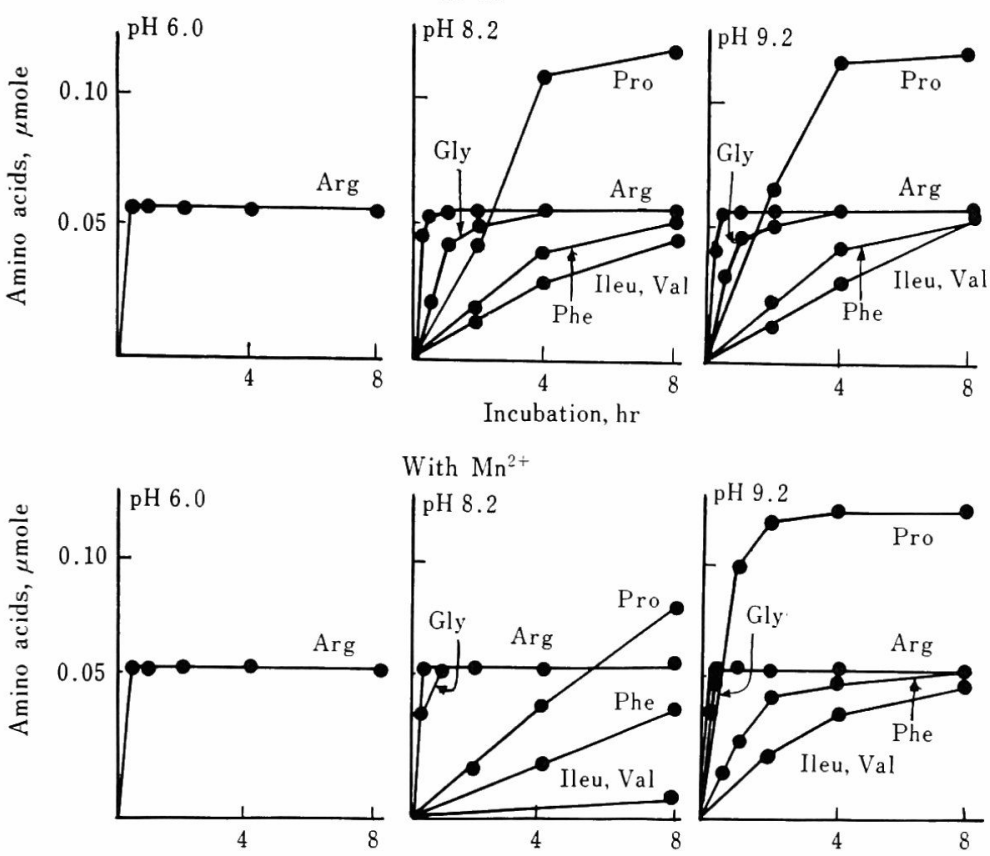

With $\mathrm{Mn}^{2+}$

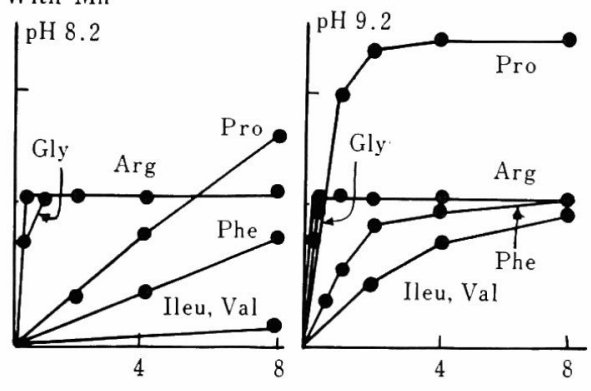

Incubation, hr

FIG. 6. Progressive Curves of Hydrolysis of BPIa with Aminopeptidase (SAPI).

BPIa, $0.5 \%$; aminopeptidase, $1.2 \mathrm{U}$; metal ions, $\mathrm{M} / 400$; buffer, $\mathrm{M} / 40$; total vol., $0.4 \mathrm{ml} ; 30^{\circ} \mathrm{C}$.

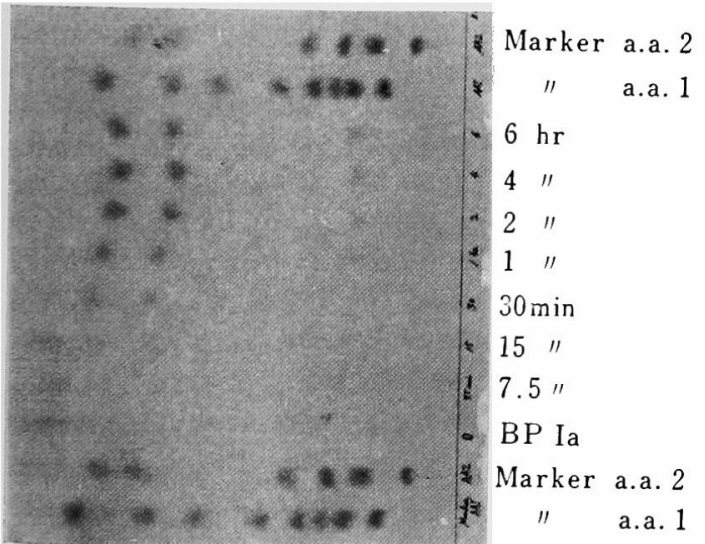

FIG. 7. Hydrolysis of BPIa with Carboxypeptidase.

lysis of BPIa with the aminopeptidase. As can be seen from Fig. 6, liberation of amino acids by the peptidase was significantly in-

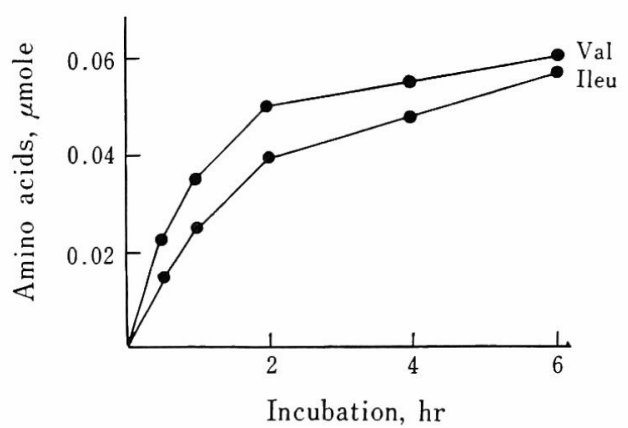

FIG. 8. Progressive Curves of Hydrolysis of BPIa with Carboxypeptidase.

BPIa, $0.5^{\circ}$; carboxypeptidase, $2.0 \mathrm{U}$; tris-buffer, $\mathrm{M} / 40, \mathrm{pH} 7.4$; total vol., $0.4 \mathrm{ml} ; 30^{\circ} \mathrm{C}$.

fluenced by $\mathrm{pH}$ of the reaction mixture and by the kind of metal ions added, indicating that the adequate control of these influencing 
factors makes it easier to determine the amino acid sequence of peptides by the enzyme. The experiment clearly showed that Arg was at first split off and following this, Gly, Pro, Pro, Phe, (Ileu, Val) were liberated in order. The C-terminal amino acid was determined by carboxypeptidase A. As shown in Fig. 7 and 8, carboxypeptidase A liberated only $\mathrm{Val}$ and Ileu in the order from BPIa. Thus, the whole amino acid sequence of BPIa will be as

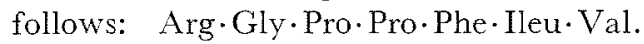

4. Amino acid sequence of BPIa and the bitterness BPIa was incubated with several proteolytic enzymes and the bitterness was investigated by the sensory test. Trypsin split off Arg of the peptides, but the bitterness was not affected. Carboxypeptidase A liberated Val and Ileu from the C-terminus, but the residual peptide was still bitter. Neutral proteinase of Bacillus subtilis split the peptide to produce Arg.Gly.Pro.Pro.Phe and Ileu.Val as described above. However, as was presumed from the experimental results by carboxypeptidase A, the hydrolysate was bitter. On the other hand, incubation with aminopeptidase resulted in loss of the bitterness and the progressive paper chromatography carried out with the incubation mixture revealed that the mixture whose bitterness had just lost gave only Arg and Gly as a free amino acid. However, BPIa incubated at $\mathrm{pH} 6.0$ with the aminopeptidase was bitter, although the $\mathrm{N}$ terminal Arg was quantitatively liberated. These results suggest that the bitterness of the peptide is due to the peptide core consisting of Gly.Pro.Pro.Phe.

\section{DISCUSSION}

The present paper shows that digestion of milk casein with alkaline proteinase of Bacillus subtilis results in formation of several bitter peptides, and one of the purpose of our study is to clarify the relationship between the bitterness and amino acid sequence of these peptides.

In our previous paper, ${ }^{21}$ bitter peptide consisting of nearly twelve kinds of amino acids was isolated from casein digests with neutral proteinase of Bacillus subtilis. Taking the action patterns of proteolytic enzymes into consideration, it is most likely that some of bitter peptides are common in the amino acid sequence of a certain site of peptide chain which is thought to be a bitter core.

It is of particular interest that our bitter peptide of which amino acid sequence was determined by the present study had the same amino acid composition with the bitter peptide isolated by Hata et al. ${ }^{81}$ from trypsin digests of milk casein, only that ours contained another amino acid "Arg" as the N-terminal amino acid. This difference seems to be quite reasonable because Hata's group employed trypsin. However, our peptide was different from theirs in the amino acid sequence as shown below:

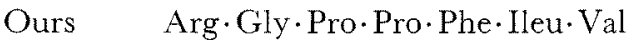 \\ Hata's Gly.Pro.Phe.Pro.Val.Ileu}

In our experiment, determination of the amino acid sequence was performed using aminopeptidase and carboxypeptidase $\mathrm{A}$ and the result was quite consistent with the one obtained by analysis of the DNP-derivatives from the hydrolysate of the bitter peptide (BPIa) with several proteolytic enzymes. Hata's groups, on the other hand, employed the Edman's method for amino acid sequence determination and the result was reported as a short communication referring our reports. Since there are various kinds of bitter peptides in the proteolytic digests of casein, it is not curious that our peptide, BPIa, might be originally different from Hata's.

Another interesting fact obtained in the present study is that the bitter peptide, BPIa, was shown to be still bitter, even if the Cterminal amino acid, $\mathrm{Val}$ and Ileu, and $\mathrm{N}$ terminal amino acid, Arg, were removed. The residual peptide might be a bitter core, 
but a further detailed study about this will be left in the future. Also, investigations of amino acid sequence of some of the bitter peptides other than BPIa will be published elswhere.

\section{REFERENCES}

1) K. Ichikawa. T. Lamamoto and J. Fukumoto, Nippon Nogeikagaku Kaishi, 33, 1044 (1959).

2) K. Ichikawa, T. Yamamoto, A. Nishio and J.
Fukumoto, Nippon Nogeikagaku Kaishi $\mathbf{3 4}, \quad+48$ (1960).

3) D. Tsuru, H. Kira, T. Yamamoto and J. Fukumoto, Agr. Biol. Chem., 30, 126I (1966).

4) N. Minamiura, Y. Matsumura, T. Lamamoto and J. Fukumoto, ibid., 33, 653 (1969).

5) E. M. Yemm and Cocking. Analyst, 80, 209 (1955).

6) F. Sanger, Biochem. J., 39, 507 (1945).

7) J. Leggettbaitley, "Techniques in Protein Chemistry," Elsivier Publishing Co., 1968, p. 20.

8) T. Natoba, C. Nagayasu, R. Hayashi and T. Hata, .tgr. Biol. Chem., 33, 166? (1969). 